\title{
Subpopulations of $\mathrm{T}$ lymphocytes in patients with ankylosing spondylitis
}

\author{
ETHEL NILSSON AND GUNNEL BIBERFELD
}

From the Department of Rheumatology, Karolinska Hospital, Stockholm County Council Central Microbiological Laboratory, and the Department of Immunology, National Bacteriological Laboratory, Stockholm, Sweden

SUMMARY Subpopulations of human blood T lymphocytes were determined in 20 patients with ankylosing spondylitis and in 20 healthy individuals. The proportion of T lymphocytes with receptors for the Fc portion of $\mathrm{IgG}$ ( $\mathrm{T}_{\mathrm{G}}$ cells) was increased in 9 patients. The proportion of $\mathrm{T}$ lymphocytes bearing receptors for the Fc portion of $\operatorname{IgM}\left(\mathrm{T}_{M}\right.$ cells) was within the range found in healthy controls in all but 4 patients, who had a decreased level of $\mathrm{T}_{M}$ cells.

Subpopulations of human T lymphocytes have been identified on the basis of their ability to bind the $\mathrm{Fc}$ portion of either IgG ( $\mathrm{T}_{\mathrm{G}}$ cells) or $\operatorname{IgM}\left(\mathrm{T}_{\mathrm{M}}\right.$ cells). ${ }^{1-5}$ $T_{G}$ cells have been shown to have supressor effect and $T_{M}$ cells helper effect on pokeweed mitogen (PWM) induced responses and antigen-specific $B$ cell responses. ${ }^{6-8} T_{G}$ cells and $T_{M}$ cells also differ in their dose response to phytohemagglutinin in the stimulation test ${ }^{3}$ and show different morphological characteristics. $^{9}$ Recently the demonstration of a small subset of $\mathrm{T}$ lymphocytes bearing receptors for the Fc portion of $\operatorname{IgA}$ has been reported.10

When studying $T$ lymphocytes subpopulations in synovial fluid and blood of patients with various rheumatic diseases ${ }^{11}$ we encountered a case of ankylosing spondylitis with a very high level of $T_{G}$ cells and a low level of $T_{M}$ cells in the blood. In the present study we have examined $T$ lymphocyte subpopulations in the blood of patients with ankylosing spondylitis to determine if abundance of $\mathbf{T}_{\mathbf{G}}$ cells is a common feature in this disease.

\section{Materials and methods}

Twenty patients with ankylosing spondylitis treated at the department of rheumatology at the Karolinska Hospital or St Erik's Hospital, Stockholm, were studied. Healthy subjects were examined as controls. Case reports of all patients were studied.

Accepted for publication 9 November 1979

Correspondence to Dr Gunnel Biberfeld, Stockholm County Council Central Microbiological Laboratory, Box 177, 10122 Stockholm 1, Sweden.

\section{CELL SEPARATION}

Lymphocytes were purified from heparinised blood by centrifugation in a Ficoll-Isopaque (FicollPaque, Uppsala, Sweden) gradient. ${ }^{12}$ Phagocytic cells were removed with a magnet after treatment of the cell suspension with carbonyl iron $(100 \mathrm{mg}$ for $20 \mathrm{~min}$ at $37^{\circ} \mathrm{C}$ ).

$\mathrm{T}$ lymphocytes were determined and separated by rosetting with neuraminidase-treated (Behringwerke, Germany) sheep rcd blood cells $(\mathrm{SRBC}=\mathrm{E})^{13}$ followed by gradient centrifugation as described in detail previously. ${ }^{11}$ The $\mathrm{T}$ cell preparations contained $95-100 \%$ E rosette forming cells with the exception of 3 preparations which contained $93-94 \%$ E rosetting cells.

\section{ANTIBODY-OXRBC}

Anti-ox red blood cell antibodies were raised in rabbits by repeated injections intraperitoneally of $1-5 \mathrm{ml}$ of $25 \%$ OxRBC. IgM and IgG fractions were prepared from rabbit antisera by SephadexG200 gel filtration. The haemagglutination (HA) titre of concentrated IgM fractions was $1 / 64$ and of concentrated IgG fractions $1 / 128-1 / 512$. Treatment with 2-mercaptoethanol completely abolished the haemagglutinating capacity of the IgM fractions but did not change the HA titre of the IgG-fractions.

\section{PREPARATION OF OXRBC-ANTIBODY}

\section{COMPLEXES}

Equal volumes of washed $\mathrm{OxRBC}$ at a concentration of $2 \%$ and purified IgM antibody (1/4 HA unit) or IgG antibody (1/2-1/4 HA units) were mixed and 
incubated at $37^{\circ}$ for $30 \mathrm{~min}$. The $\mathrm{OxEA}_{\mathrm{G}}$ and $\mathrm{OxEA}_{\mathbf{M}}$ complexes were then washed and resuspended to a concentration of $0.5 \%$.

\section{DETERMINATION OF TG AND TM CELLS}

$T_{G}$ and $T_{M}$ cells were identified by rosette formation as described by Moretta and coworkers. ${ }^{3} 0.1 \mathrm{ml}$ of a cell suspension containing $3 \times 10^{6} \mathrm{cells} / \mathrm{ml}$ were mixed with $0.1 \mathrm{ml}$ of $\mathrm{OxEA}_{\mathrm{G}}$ or $\mathrm{OxEA}_{M}$ and centrifuged at $200 \mathrm{~g}$ for $5 \mathrm{~min}$ followed by incubation at $+4^{\circ} \mathrm{C}$ for $1 \mathrm{~h}$. The pellet was gently resuspended, and 400 lymphocytes from each tube were counted for rosette formation. A rosette was defined as a lymphocyte with 3 or more red cells attached. All tests were performed in duplicate. $T$ cells examined for OxEA $_{M}$ rosette formation had been incubated overnight at $37^{\circ} \mathrm{C}$ in RPMI-1640 medium supplemented with $20 \%$ FCS. $^{2}$ Tests for $\mathrm{T}_{\mathrm{G}}$ cells were done with freshly prepared $\mathrm{T}$ cells as well as $\mathrm{T}$ cells incubated overnight at $37^{\circ} \mathrm{C}$.

\section{ASSAY FOR DNA SYNTHESIS}

Lymphocytes purified by Ficoll-Isopaque centrifugation and carbonyl iron treatment were cultured in RPMI 1640 medium (Biocult Laboratories, Paisley, Scotland) supplemented with $10 \% \mathrm{AB}-$ serum pool, L-glutamin, penicillin, and streptomycin in microplates (3040 Microtest II, Falcon, USA). Each well contained $2 \times 10^{5}$ lymphocytes in $0.2 \mathrm{ml}$ medium. Duplicate or triplicate cultures were set up with phytohaemagglutinin (PHA) at a final concentration of $2 \cdot 5 \mu \mathrm{g} / \mathrm{ml}$ or with no additive. After 2 days of incubation at $37^{\circ} \mathrm{C}$ in humidified air with $5 \% \mathrm{CO}_{2} 0.05 \mu \mathrm{Ci}$ of ${ }^{14} \mathrm{C}$-thymidine (Radiochemical Centre, Amersham, England) was added to each well. After further incubation for 18 hours the cells were harvested with a Titertek cell harvester (Flow Laboratories, Scotland). Radioactivity was measured in a liquid scintillation counter and expressed in counts per minute (cpm) per culture.

\section{Results}

The percentages of total $\mathrm{T}$ lymphocytes, $\mathrm{T}_{\mathrm{G}}$ cells, and $\mathrm{T}_{M}$ cells in the blood of 20 patients with ankylosing spondylitis and of 20 healthy controls are shown in Tables 1 and 2. The proportion of $T_{G}$ cells among $\mathrm{T}$ lymphocytes cultured overnight was in the range $7-22 \%$ in all but 1 healthy individual, a 55-year-old woman, who had $26 \% \mathrm{~T}_{\mathrm{G}}$ cells. Eight of the patients had an increase of $\mathrm{T}_{\mathrm{G}}$ cells above $26 \%$. The $T_{G}$ cell level was considered to be slightly increased also in a 29-year-old patient (no. 3), who had $26 \% \mathrm{~T}_{\mathrm{G}}$ cells, whereas the same percentage was not considered to represent an increase above normal
Table 1 Percentages of total $T$ cells, $T_{G}$ cells and $T_{M}$ cells in the blood of 20 patients with ankylosing spondylitis

\begin{tabular}{|c|c|c|c|c|c|}
\hline \multirow[t]{2}{*}{ Patient } & \multirow[t]{2}{*}{ Age/sex } & \multirow{2}{*}{$\begin{array}{l}\text { Total } \\
T \text { cells }\end{array}$} & \multicolumn{2}{|c|}{$T_{G}$ cells } & \multirow[t]{2}{*}{$T_{M}$ cells } \\
\hline & & & $\begin{array}{l}\text { Not } \\
\text { cultured }\end{array}$ & $\begin{array}{l}\text { Cultured } \\
\text { overnight }\end{array}$ & \\
\hline 1 & $28 / \mathrm{M}$ & 73 & ND & 6 & 73 \\
\hline 2 & $28 / M$ & 84 & 14 & 15 & 54 \\
\hline 3 & $29 / \mathrm{F}$ & $\mathrm{ND}^{*}$ & ND & 26 & 69 \\
\hline 4 & $30 / F$ & 78 & ND & 13 & 63 \\
\hline 5 & $31 / \mathbf{M}$ & 75 & 37 & ND & 35 \\
\hline 6 & $32 / \mathrm{M}$ & 82 & ND & 9 & 53 \\
\hline 7 & $33 / \mathbf{M}$ & 74 & 28 & 27 & 60 \\
\hline 8 & $34 / \mathrm{M}$ & 76 & 20 & 18 & ND \\
\hline 9 & $37 / \mathbf{M}$ & ND & 20 & 18 & 69 \\
\hline 10 & $38 / \mathrm{M}$ & 74 & 19 & 18 & 52 \\
\hline 11 & $39 / \mathbf{M}$ & 63 & 27 & 30 & 63 \\
\hline 12 & $40 / \mathrm{M}$ & 70 & 19 & 13 & 69 \\
\hline 13 & $44 / F$ & 79 & 28 & 34 & 63 \\
\hline 14 & 49/M & ND & ND & 30 & 63 \\
\hline 15 & $49 / F$ & 75 & ND & 32 & 43 \\
\hline 16 & $51 / \mathrm{M}$ & 73 & 32 & 30 & 46 \\
\hline 17 & $55 / \mathrm{M}$ & 82 & ND & 26 & 57 \\
\hline 18 & $57 / \mathrm{M}$ & ND & ND & 10 & 34 \\
\hline 19 & $59 / \mathrm{M}$ & 72 & 78 & 81 & 15 \\
\hline 20 & $72 / \mathrm{M}$ & 75 & 28 & 23 & 35 \\
\hline Mean & & 73 & & $25^{* *}$ & 53 \\
\hline SD & & 5 & & 16 & 15 \\
\hline
\end{tabular}

${ }^{*} \mathrm{ND}=$ not done. ${ }^{* *}$ In patient 5 the proportion of $\mathrm{T}_{\mathrm{G}}$ cells was not determined with cultured $T$ cells. In this case the $T_{G}$ cell percentage obtained with fresh $\mathrm{T}$ cells $(37 \%)$ has been included in the calculation of the mean of the proportion of $T_{G}$ cells.

Table 2 Percentages of total $T$ cells, $T_{G}$ cells, and $T_{M}$ cells in the blood of 20 healthy subjects

\begin{tabular}{|c|c|c|c|c|c|}
\hline \multirow[t]{2}{*}{ Subject } & \multirow[t]{2}{*}{ Age/sex } & \multirow{2}{*}{$\begin{array}{l}\text { Total } \\
T \text { cells }\end{array}$} & \multicolumn{2}{|l|}{$T_{G}$ cells } & \multirow[t]{2}{*}{$T_{M}$ cells } \\
\hline & & & $\begin{array}{l}\text { Not } \\
\text { cultured }\end{array}$ & $\begin{array}{l}\text { Cultured } \\
\text { overnight }\end{array}$ & \\
\hline $\begin{array}{l}1 \\
2 \\
3 \\
4 \\
5 \\
6 \\
7 \\
8 \\
9 \\
10 \\
11 \\
12 \\
13 \\
14 \\
15 \\
16 \\
17 \\
18 \\
19 \\
20 \\
\text { Mean } \\
\text { SD }\end{array}$ & $\begin{array}{l}21 / \mathrm{F} \\
28 / \mathrm{M} \\
31 / \mathrm{F} \\
32 / \mathrm{F} \\
34 / \mathrm{F} \\
35 / \mathrm{M} \\
35 / \mathrm{M} \\
35 / \mathrm{M} \\
36 / \mathrm{F} \\
36 / \mathrm{M} \\
37 / \mathrm{F} \\
38 / \mathrm{M} \\
40 / \mathrm{M} \\
43 / \mathrm{F} \\
45 / \mathrm{M} \\
53 / \mathrm{M} \\
53 / \mathrm{M} \\
54 / \mathrm{M} \\
55 / \mathrm{F} \\
58 / \mathrm{M}\end{array}$ & $\begin{array}{c}83 \\
85 \\
71 \\
87 \\
78 \\
69 \\
81 \\
76 \\
88 \\
76 \\
85 \\
69 \\
91 \\
87 \\
60 \\
84 \\
73 \\
60 \\
73 \\
79 \\
78 \\
9\end{array}$ & $\begin{array}{l}17 \\
14 \\
\text { ND } \\
15 \\
14 \\
8 \\
13 \\
17 \\
6 \\
\text { ND } \\
\text { ND } \\
13 \\
23 \\
12 \\
12 \\
\text { ND } \\
16 \\
20 \\
29 \\
19 \\
-\end{array}$ & $\begin{array}{r}13 \\
13 \\
21 \\
10 \\
13 \\
8 \\
12 \\
17 \\
7 \\
20 \\
20 \\
17 \\
13 \\
13 \\
14 \\
19 \\
17 \\
22 \\
26 \\
20 \\
16 \\
5\end{array}$ & $\begin{array}{l}73 \\
59 \\
61 \\
50 \\
62 \\
56 \\
73 \\
\text { ND } \\
52 \\
43 \\
57 \\
52 \\
45 \\
79 \\
67 \\
60 \\
52 \\
50 \\
68 \\
45 \\
58 \\
10\end{array}$ \\
\hline
\end{tabular}

in a 55-year-old patient (no. 17). (The percentage of $T_{G}$ cells has been shown to be increased in aging subjects when compared with young subjects. ${ }^{14}$ ) In 8 of the patients the increase of $T_{G}$ cells was slight or moderate $\left(26-37 \% \mathrm{~T}_{\mathrm{G}}\right.$ cells), whereas 1 
patient, reported previously, ${ }^{11}$ had an extremely high level of $T_{G}$ cells $(81 \%)$. The level of significance of the difference between the mean of the proportion of $T_{G}$ cells in patients and controls was $\mathrm{P}<0.05$.

There were usually only small differences in the proportion of $T_{G}$ cells between freshly prepared $T$ cells and $T$ cells incubated overnight (Tables 1 and 2 ). However, in 1 healthy subject (no. 13, Table 2) incubation of $\mathrm{T}$ cells overnight resulted in a considerably lower percentage of $\mathrm{T}_{\mathbf{G}}$ cells. The proportion of $T_{M}$ cells ranged from 43 to $79 \%$ in the healthy subjects (Table 2). In all but 4 patients the proportion of $T_{M}$ cells was within the normal range (Table 1). Three of these patients had a slightly decreased level of $T_{M}$ cells and the third patient a very low level of these cells.

There was no significant difference in the proportion of total $\mathrm{T}$ cells between patients and controls.

The group of patients with an increased level of $T_{G}$ cells did not differ significantly from the group of patients with a normal level of $T_{G}$ cells with regard to age, duration of the disease, clinical activity of the disease, occurrence of extra-articular symptoms (prostatitis, colitis, iritis), or medical treatment.

The lymphocyte stimulation response to an optimal dose of PHA was determined in 18 patients and in 11 healthy subjects. There was no significant difference in PHA responsiveness between patients (mean cpm $\pm \mathrm{SD}=17787 \pm 9834$ ) and controls (13 $392 \pm$ 9447).

\section{Discussion}

This study showed that almost $50 \%$ of patients with ankylosing spondylitis had a slight or moderate increase in the proportion of $T_{G}$ cells. Only 1 patient had a very high proportion of $\mathrm{T}_{\mathrm{G}}$ cells. Imbalances in $\mathrm{T}$ lymphocyte subpopulations have previously been demonstrated in some other diseases. An increase in the proportion of $\mathbf{T}_{\mathbf{G}}$ cells has been found in certain immunodeficiency diseases, ${ }^{6} 715$ multiple sclerosis, ${ }^{16}$ sarcoidosis, ${ }^{17}$ and myasthenia gravis. ${ }^{18} \mathrm{~A}$ transient rise of $\mathrm{T}_{\mathrm{G}}$ cells may occur in certain acute viral infections, for instance, influenza, acute hepatitis (Moretta, personal communication), and vaccine-induced rubella (Arneborn, Biberfeld, and Wasserman, in preparation). The cause of the $T_{G}$ cell increase in various disorders is not clear. One possibility is that a strong antigen stimulation may trigger a selective increase of $T_{G}$ cells.

$A$ reduced level of $T_{G}$ cells ${ }^{19-21}$ and impairment of the suppressor cell activity ${ }^{19-25}$ have been demonstrated in patients with SLE. We have no data on the suppressor cell function in patients with ankylosing spondylitis. However, the finding of raised immunoglobulins in patients with ankylosing spondylitis ${ }^{26} 27$ seems to speak against an enhanced suppressor effect on B cells in these patients.

A decrease in the percentage of $T$ cells in patients with ankylosing spondylitis has been reported, ${ }^{28}$ whereas in the present study no significant difference in $T$ cell percentages between patients and healthy subjects was found. This discrepancy may be due to technical differences in the performance of the $E$ rosette test.

The lymphocyte stimulation response to an optimal dose of PHA did not differ significantly between patients and healthy subjects in the present study and in a study by Fan et al. ${ }^{28}$ However, it has been reported that patients with ankylosing spondylitis have a depressed lymphocyte stimulation response to a suboptimal dose of PHA. ${ }^{29}$ Alteration of $\mathrm{T}$ lymphocyte subpopulations may influence the stimulation response to PHA. ${ }^{3}$

The skilled technical assistance of Margareta Andersson and Margareta Söderqvist is gratefully acknowledged. This work was supported by the Swedish Medical Research Council (project no. 16-X-2380), the Swedish National Association against Rheumatism, and King Gustav V 80årsfond. We are grateful to the department of rheumatologyg St Erik's Hospital, for providing some of the blood samples

\section{References}

1 Ferrarini M, Moretta L, Abrile R, Durante M L. Receptors for IgG molecules on human lymphocytes forming spontaneous rosettes with sheep red cells. Eur $J$ Immunol 1975; 5: 70-2.

2 Moretta L, Ferrarini M, Durante M L, Mingari M C. Expression of a receptor for IgM by human $\mathrm{T}$ cells in vitro. Eur J Immunol 1975; 5: 565-9.

3 Moretta L, Ferrarini M, Mingari M C, Moretta A, Webb S. Subpopulations of humans $T$ cells identified by receptors for immunoglobulins and mitogen responsiveness. J Immunol 1976; 117: 2171-4.

4 McConnell I, Hurd C M. Lymphocyte receptors. II. Receptors for rabbit IgM on human $\mathrm{T}$ lymphocytes. Immunology 1976; 30: 836-9.

5 Gmeling-Meyling F, van der Ham M, Bollieux R. E. Binding of IgM by human T lymphocytes. Scand $J$ Immunol 1976; 5: 487-95.

6 Moretta L, Mingari M C, Webb S R, et al. Imbalance in T-cell subpopulations associated with immunodeficiency and autoimmune syndromes. Eur J Immunol 1977; 7: 696-700.

7 Moretta L, Webb S R, Grossi C E, Lydyard P M, Cooper $M$ D. Functional analysis of two human T-cell subpopulations: help and suppression of $\mathrm{B}$ cell response by $\mathrm{T}$ cell bearing receptors for $\operatorname{IgM}\left(\mathrm{T}_{\mathrm{M}}\right)$ at $\operatorname{IgG}\left(\mathrm{T}_{\mathrm{G}}\right)$. J Exp Med 1977; 146: 184-200.

8 Heijnen C J, Uytdehaag F, Gmelig-Meyling F H J, Ballieux R E. Localization of human antigen-specific $\stackrel{\mathcal{S}}{+}$ helper and suppressor function in distinct $\mathrm{T}$-cell subpopulations. Cell Immunol 1979; 43: 282-92.

9 Grossi C E, Webb S R, Zicca A. et al. Morphological and histochemical analyses of two human T-cell subpopulations bearing receptors for IgM and IgG. $J$ Exp Med 1978: 147: 1405-17. 
10 Lum L G, Muchmore A V, Keren D et al. A receptor for IgA on human $T$ lymphocytes. J Immunol 1979; 122: 65-9.

11 Biberfeld G, Nilsson E, Biberfeld P. T lymphocyte subpopulations in synovial fluid of patients with rheumatic disease. Arthritis Rheum 1979; 22: 978-82.

12 Bøyum A. Isolation of lymphocytes, granulocytes and macrophages. Scand J Immunol 1976; 5 (Suppl. 5): 9-15.

13 Jondal M. SRBC rosette formation as a human $T$ lymphocyte marker. Scand J Immunol 1976; 5: 69-76.

14 Gupta S, Good R A. Alterations in T, B, third population cells and $T$ cells with receptor for immunoglobulin ${ }^{M}(T \mu)$ or $G(T \gamma)$ in aging humans. J Immunol 1979; 122: 1214-9.

15 Gupta S, Good R A. Subpopulations of human T lymphocytes. V. T lymphocytes with receptors for immunoglobulin $\mathbf{M}$ or $\mathbf{G}$ in patients with primary immunodeficiency disorders. Clin Immunol Immunopathol 1978; 11 : 292-302.

16 Santoli D, Moretta L, Lisak K, Gilden D, Koprowski H. Imbalances in $\mathrm{T}$ cell subpopulations in multiple sclerosis patients. J Immunol 1978; 120: 1369-471.

17 Katz P, Haynes E F, Fauci A S. Alteration of T lymphocyte subpopulations in sarcoidosis. Clin Immunol Immunopathol 1978; 10: 350-4.

18 Piantelli M, Lavriola L, Carbone A, Evoli A, Tonali P, Musiani P. Subpopulations of T lymphocytes in myasthenia gravis patients. Clin Exp Immunol 1979; 36: 85-9.

19 Fauci A S, Steinberg A D, Haynes B F, Whalen G. Immunoregulatory aberrations in systemic lupus erythematosus. J Immunol 1978; 121 : 1473-9.

20 Hamilton M E, Winfield G B. T $\gamma$ cells in systemic lupus erythematosus. Variation with disease activity. Arthritis Rheum 1979; 22 : 1-6.

21 Newman B, Blank S, Lomnitzer R, Disler P, Rabson A. Lack of suppressor cell activity in systemic lupus erythematosus. Clin Immunol Immunopathol 1979; 13: 187-93.

22 Abdou N I, Sagawa A, Pascual E, Hebert H, Sadeghee S. Suppressor T-cell abnormality in idiopathic systemic lupus erythematosus. Clin Immunol Immunopathol 1976; 6: 192-9.

23 Bresnihan B, Jasin H E. Suppressor function of peripheral blood mononuclear cells in normal individuals and in patients with systemic lupus erythematosus. J Clin Invest 1977; 59: 106-16.

24 Horowitz S, Borsberdin W, Moorthy V A, Chesney R, Schulte-Wisserman H. Hong R. Induction of suppressor $T$ cells in systemic lupus erythematosus by thymosin and cultured thymic epithelium. Science 1977; 197: 999-1001.

25 Sakane T I, Steinberg A, Green I. Dysfunction of suppressor T-cell activity related to impaired generation of rather than response to suppressor cells. Arthritis Rheum 1978; 21: 657-74.

26 Veys E M, Van Laere M. Serum IgG, IgM and IgA in ankylosing spondylitis. Ann Rheum Dis 1973 ; 32: 493-496.

27 Eghtedari A A, Davis P, Bacon P A. Immunological reactivity in ankylosing spondylitis. Ann Rheum Dis 1976; 35: 155-7.

28 Fan P T, Clement P J, Yu D T Y, Opetz G, Bluestone R. Lymphocyte abnormalities in ankylosing spondylitis. Ann Rheum Dis 1977; 36: 471-3.

29 Sturrock R D, Froebel K, MacSween R N M, Dick W C. Evidence of impaired cell mediated immunity in the seronegative arthritides. Ann Rheum Dis 1975; 34: 203. 